\title{
JUSTIFICATION OF OPTIMAL LOCATION OF CONNECTION OF THE DISTRIBUTED GENERATION SOURCE AND VALUE OF ITS POWER
}

Goal. To analyze the options for the development of the $110 \mathrm{kV}$ electricity network with sources of distributed generation. Establishing the relationship between power of the source of distributed generation with the voltage changes in the nodes and transformer active power losses change. To provide the minimum value of network active power loss the authors justify the conditions for optimal connection of the source of distributed generation and value of its power. Methodology. The authors have used the DigSilent Power Factory software environment to create a $110 \mathrm{kV}$ network model and have made a series of simulation of the network operating modes with solar power plants. Results. Based on the operational parameters it is established that the change in power generation in the accepted limits normally does not lead to abnormal voltage variations in the nodes, with power losses having characteristic changes due to alterations in the network of power flows. In the network with solar power plants, the transformer losses of active power is reduced with increasing generation power, except for the most remote nodes from the balancing point, in which losses reduction takes place with load of transformers approximately up to $60 \%$. At significant overloads of transformers (up to $130 \%$ ) there is reactive power losses increasing in comparison with losses in the network without solar power plants. The dependence of active power losses in the network on the load of transformers has a nonlinear character). For each node at one value of transformer load the active losses are different. Less reactive power losses occur at lower load ratios of transformer. When increasing the load of transformers, the rate of increase in reactive losses is higher than the active ones. Also for closed networks with voltage of $110 \mathrm{kV}$ it has been found that the optimal node for connecting the distributed generation is a node with a flow division of power. If there are several such nodes in the network, the optimal one for connecting is the node with the maximum load. The optimal power of the solar station in the node should not exceed $110 \%$ of the installed transformer's power. Originality. For the first time the dependence between the place of the best connection source of the distributed generation with the point of flow distribution with the greatest current fraction from network balancing point was established. In this case the power of the source of distributed generation must not exceed $10 \%$ of the total power of the transformers in this node. Practical significance. We have obtained reasonable conditions for connecting source of distributed generation to a closed electric network of $110 \mathrm{kV}$ without performing large volumes of mode calculations. Namely, the optimal connection point is the point of flow distribution with the greatest current fraction from network balancing point. References 8 , tables 3, figures 5.

Key words: source of distributed generation, flow distribution, load factor of transformer, power losses, voltage, power factory, solar power station.

Висвітлено підхід до визначення потужнноті джерела розосередженого генерування (ДРГ) та оптимального місця його підключення для забезпечення мінімального значення втрат активної потужяності в замкненій електричній мережі напругою 110 кВ. Виконано аналіз впливу потужності сонячної електростанцї̈ на режимні параметри мережі. Запропоновано критерій визначення значення потужності ДРГ в вузлах можливого підключення. Розроблено рекомендації до визначення оптимального вузла підключення джерела розосередженого генерації відповідної потужнності. Бібл. 8, табл. 3, рис. 5 .

Ключові слова: джерела розподіленої генерації, потокорозподіл, коефіціснт завантаження трансформатора, втрати потужності, напруга, сонячна електростанція .

Освещено подход к определению мощности источника рассредоточенной генерации (ИРГ) и оптимального его подключения для обеспечения минимального значения потерь активной мощности в замкнутой электрической сети напряжением 110 кВ. Выполнен анализ влияния мощности солнечной электростанции на режимные параметры сети. Предложен критерий определения значения мощность ИРГ в узлах возможного подключения. Разработаны рекомендации к определению оптимального узла подключения источника рассредоточенного генерации соответствующей моцности. Библ. 8, табл. 3, рис. 5.

Ключевые слова: источники распределенной генерации, потокораспределение, коэффициент загрузки трансформатора, потери мощности, напряжение, солнечная электростанция.

Introduction. In the united power grid of Ukraine, which is a system-forming branch, significant changes are taking place. The centralized way of functioning of the electric power system has exhausted its reserves. The cost-extensive principle of raw materials (primarily carbon and uranium) energy has led the industry to inevitably increasing costs to maintain the parameters of electrical equipment and networks within their operational reliability.

Positive changes in the development of traditional energy are undoubtedly at the minimum and further functioning can take place in the direction of: the final collapse and the achievement of the point of non-recovery and destruction of the power system; or in the direction of qualitative reformatting of the structure and philosophy of functioning of the electric power industry, orientation to the resourceless generation of renewable energy sources (RES) on the principles of virtualization, with the introduction of self-guided on the local levels «Smart Grids», with the development of distribution networks based on the introduction of new levels of voltage to reduce power losses, improvement and development of network topology.

World experience shows that with the increase of the share of distributed generation, including on the basis of 
renewable energy sources, there is a need to solve a number of problems: the stochastic nature of electricity production, ensuring the reliable operation of distributed generation (DG) objects in the composition of the electricity system with a change of approach to modetechnological design, planning and management, regulation of frequency and voltage of DG objects, ensuring the reliability and quality of power supply of consumers, secured stable operation of distributed generation sources (DGS). In Ukraine, these problems are connected, on the one hand, with the state, operation and features of the construction of electric networks, on the other one - with the peculiarities of the functioning of the DGS itself in normal and emergency conditions. The introduction of DGS has a significant impact on the operation of the united power grid and requires the coordinated operation of system operators of trunk, district and distribution networks in the planning and monitoring of real-time operation modes [1].

Another problem that arises during the design phase is the choice of the optimal place for connecting the DGS to the electrical network, since this factor greatly affects the power losses in the network as a whole. The desire of the consumer to enter the power of DGS does not always coincide with the technical capabilities of the network. The difference between power losses, in the case when the DGS is connected in the optimal and least optimal nodes, may exceed $10 \%$ [2].

In recent decades, many authors have proposed new methods for optimizing the search for the location and power of the DG source. Researchers [5] considered the problem of finding a place for the installation of DGS using a genetic algorithm to minimize the active power flow across the network. In [6], two methods for locating sources search are combined with a mix of the genetic algorithm and the simulation meta-heuristic method of selection. The authors of [7] applied the algorithm of the search tab (local search) to simultaneously search for the location of the DG source installation with the installation of a source of reactive power in the network. In [8], an optimization method based on colony of ants was proposed as a means of solving the search for places and power of DGS. For this method, the target function was minimized based on the total cost of the network.

However, determination of the optimal place of installation and power of DGS sources is not an end to the investigated issue, because in many cases, instead of the expected improvement of the parameters of the electric network, their deterioration is observed. In this regard, in the paper two important tasks are considered in the course of the introduction of DRG, namely, the search for optimal power and location of the source.

The goal of the work is to substantiate the choice of the optimal location of the source of distributed generation connection and the value of its power to provide the minimum value of active power losses in the network.

In distribution networks, the voltage drop goes along the direction of electricity supply to customers, from the main section of the power transmission line (PTL) to its end. After the DGS is installed, in such an electrical network the load on the feeder is reduced, and the voltage along the PTL may increase. Important in this case is the power factor of the DGS. The value of the voltage change depends on the location of the DGS installation, its power and $\cos \varphi$ (generation or consumption) [3].

It should also be noted that the active and reactive load of nodes varies with time, which in turn causes certain fluctuations in the voltage level in the network. In the direction from the main section to the end of the PTL, the voltage fluctuations tend to increase. If the load is concentrated mainly at the end of the PTL or remote from the balancing point, the voltage level will fluctuate more intensively [4].

The introduction of DGS into the electrical network leads to changes in its mode parameters: there is a redistribution of power over the PTL and, accordingly, change the profile of the voltage in the network. Important is the place, that is, the node of the connection of the DGS, and its power.

The installation of DGS in a closed district electrical network (DEN) with random power generation change can change the direction of power flows. In the preliminary determination of the DGS connection node and its power, it is necessary to take into account three possible situations with regard to the nodal load and the power of the DGS in the district electric network:

1. The own load of each node in the network is greater than or equal to the output power of the DGS connected to this node.

2. In DEN there is at least one node where the output power of the DGS is greater than the own load of this node, but the total power of the DGS of this DEN is in general less than its total load.

3. There is at least one node in the network where the output power of the DGS is greater than the own load of this node and the total power of the DGS of this network in general is larger than its total load.

In the first case, the installed DGS in the network will affect the reduction of power losses in the network. In the second case, DGS can permanently increase power losses in some PTLs, but overall, total power losses in DEN are reduced. In the third case, the total power losses of the entire network will be greater than before the installation of the DGS.

Thus, the installation of DGS can both increase and decrease power losses in DEN, which mainly depends on the connection nodes in the network, the power of the DGS in the network, their power factor, as well as the network topology.

To justify the expediency of optimal input of DGS power at the nodes of a closed electric network, a startup project was developed, the main idea of which is to improve an existing electricity network by connecting a new substation to provide a service for reliable electricity supply to consumers and compare possible circuits for connecting a substation to a network with competitive variants with similar technical and economic indicators. Thus, calculations of the mode parameters of five test 8node closed networks with voltage of $110 \mathrm{kV}$ of different configurations were carried out and the analysis of the 
influence of distributed generation sources on the network operation mode was performed. In this case, variants of connection of DGS with possible generation power in the range from 13 to $31 \mathrm{MW}$ with a $2 \mathrm{MW}$ step for each of the nodes of the circuit are considered. As a conditional source of distributed generation, a solar photovoltaic station (SPS) is selected on condition of acceptable weather and territorial factors of its operation in the network, that is, the influence of generation on the system operating parameters such as voltage in nodes and power losses in the lines are considered, without taking into account the stochastic nature of the power.

The analysis of the mode parameters was performed within 80 steady operating modes, calculated in the software environment DigSilent Power Factory, for each of the five electrical networks.

Figure 1 shows one of five circuits of the electrical network, for which the analysis of the mode parameters was performed at the input of distributed generation in the network nodes.

Table 1 shows the values of the nominal voltages and powers of the transformers installed in the network nodes of the presented circuit.

Parameters of transformers in the nodes of the network

\begin{tabular}{|c|c|c|c|c|}
\hline Node No. & 1 & 2 & 3 & 4 \\
\hline$U_{\text {tr }}, \mathrm{kV}$ & $110 / 35 / 10$ & $110 / 35 / 10$ & $110 / 35 / 10$ & $110 / 35 / 10$ \\
\hline$S_{\text {tr }}, \mathrm{MVA}$ & 25 & 10 & 10 & 16 \\
\hline Node No. & 5 & 6 & 7 & 8 \\
\hline$U_{\mathrm{tr}}, \mathrm{kV}$ & $110 / 10$ & $110 / 35 / 10$ & $110 / 35 / 10$ & $110 / 35 / 10$ \\
\hline$S_{\text {tr }}, \mathrm{MVA}$ & 10 & 16 & 10 & 16 \\
\hline
\end{tabular}

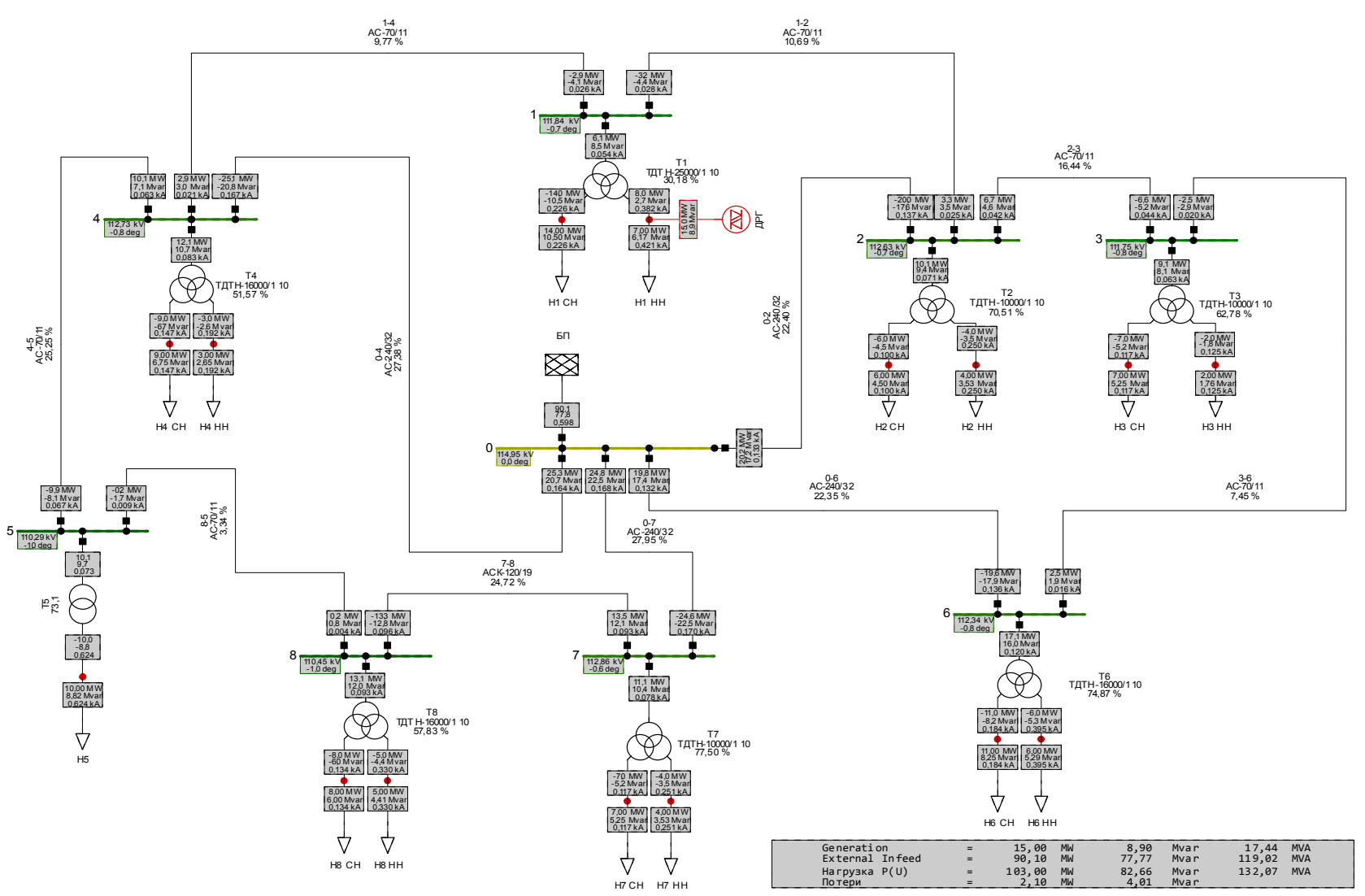

Fig. 1. Calculation model of the circuit of the electric network with DGS in the first node in the software environment DigSilent

Power Factory
Table 2 shows for the selective capacities $(13,23$ and $31 \mathrm{MW}$ ) of the solar power plant at the network nodes the calculated voltage levels at the voltage value of $115 \mathrm{kV}$ level at the balancing point «0» (BP).

From Table 2 it is shown that the change in generation power in the accepted limits does not cause excessive voltage deviations in the nodes in the normal mode, and network losses due to change in power flows have characteristic changes.

Based on the simulation data of the modes, the following graphic dependencies of the active (Fig. 2) and reactive (Fig. 3) power losses on the load of transformers in the network nodes were obtained, as well as the dependence of the losses of active power on generation power (Fig. 4).

In Fig. 2, 3 in the first node there is an uncharacteristic for other nodes decline of power losses curve. This type of curve is due to the fact that at the highest power of the transformer at this point of the network (through the power lines of the node significant power flows are flowing) at the increase in SPS power there is a significant unloading of the transformer and the reduction of power flows along the lines and, consequently, reducing the power losses in them and increase the voltage level in the node.

Table 3 shows the values of active and reactive power losses in the network when the transformers are loaded in the nodes for selective power values of the SPS. 
Table 2

Voltage values in the nodes of the circuit $110 \mathrm{kV}$

\begin{tabular}{|c|c|c|c|c|c|c|c|c|c|}
\hline$P_{\mathrm{SPS}}$ & $\begin{array}{l}\text { Point in which } \\
\text { SPS is connected }\end{array}$ & $U_{1}, \mathrm{kV}$ & $U_{2}, \mathrm{kV}$ & $U_{3}, \mathrm{kV}$ & $U_{4}, \mathrm{kV}$ & $U_{5}, \mathrm{kV}$ & $U_{6}, \mathrm{kV}$ & $U_{7}, \mathrm{kV}$ & $U_{8}, \mathrm{kV}$ \\
\hline 1 & 2 & 3 & 4 & 5 & 6 & 7 & 8 & 9 & 10 \\
\hline $0 \mathrm{MW}$ & - & 109.6 & 111.91 & 111.24 & 112.2 & 109.95 & 112.17 & 112.8 & 110.27 \\
\hline \multirow{8}{*}{$13 \mathrm{MW}$} & 1 & 111.56 & 112.54 & 111.68 & 112.67 & 110.25 & 112.32 & 112.85 & 110.43 \\
\hline & 2 & 110.2 & 112.84 & 111.9 & 112.32 & 110.03 & 112.39 & 112.81 & 110.31 \\
\hline & 3 & 110.01 & 112.55 & 112.84 & 112.28 & 110.00 & 112.75 & 112.81 & 110.29 \\
\hline & 4 & 110.04 & 112.03 & 111.32 & 113 & 110.47 & 112.19 & 112.89 & 110.54 \\
\hline & 5 & 109.88 & 111.98 & 111.29 & 112.72 & 112.21 & 112.18 & 113.22 & 111.54 \\
\hline & 6 & 109.75 & 112.14 & 111.86 & 112.22 & 109.97 & 113.41 & 112.9 & 110.28 \\
\hline & 7 & 109.64 & 111.92 & 111.24 & 112.28 & 110.37 & 112.17 & 113.64 & 110.93 \\
\hline & 8 & 109.75 & 111.95 & 111.26 & 112.48 & 111.24 & 112.18 & 113.48 & 112.32 \\
\hline \multirow{8}{*}{$23 \mathrm{MW}$} & 1 & 112.9 & 112.95 & 112 & 112.98 & 110.45 & 112.41 & 112.88 & 110.53 \\
\hline & 2 & 110.54 & 113.4 & 112.3 & 112.4 & 110.07 & 112.5 & 112.82 & 110.32 \\
\hline & 3 & 110.24 & 112.92 & 113.84 & 112.32 & 110.03 & 113.07 & 112.81 & 110.3 \\
\hline & 4 & 110.32 & 112.1 & 111.37 & 113.54 & 110.8 & 112.2 & 112.94 & 110.71 \\
\hline & 5 & 110.06 & 112.03 & 111.32 & 113.05 & 113.74 & 112.2 & 113.48 & 112.36 \\
\hline & 6 & 109.8 & 112.28 & 112.26 & 112.23 & 109.97 & 114.21 & 112.8 & 110.28 \\
\hline & 7 & 109.67 & 111.92 & 111.24 & 112.32 & 110.61 & 112.17 & 114.12 & 111.32 \\
\hline & 8 & 109.84 & 111.97 & 111.27 & 112.65 & 112.08 & 112.18 & 113.9 & 113.68 \\
\hline \multirow{8}{*}{$31 \mathrm{MW}$} & 1 & 113.9 & 113.27 & 112.19 & 113.2 & 110.59 & 112.48 & 112.9 & 110.6 \\
\hline & 2 & 110.77 & 113.77 & 112.54 & 112.42 & 110.09 & 112.57 & 112.82 & 110.33 \\
\hline & 3 & 110.39 & 113.16 & 114.52 & 112.34 & 110.04 & 113.28 & 112.81 & 110.31 \\
\hline & 4 & 110.51 & 112.15 & 111.4 & 113.9 & 111.03 & 112.21 & 112.97 & 110.83 \\
\hline & 5 & 110.18 & 112.08 & 111.34 & 113.29 & 114.85 & 112.19 & 113.67 & 112.98 \\
\hline & 6 & 109.89 & 112.37 & 112.53 & 112.34 & 109.98 & 114.76 & 112.8 & 110.28 \\
\hline & 7 & 109.68 & 111.92 & 111.24 & 112.35 & 110.76 & 112.17 & 114.44 & 111.58 \\
\hline & 8 & 109.9 & 111.98 & 111.28 & 112.77 & 112.66 & 112.18 & 114.2 & 114.6 \\
\hline
\end{tabular}

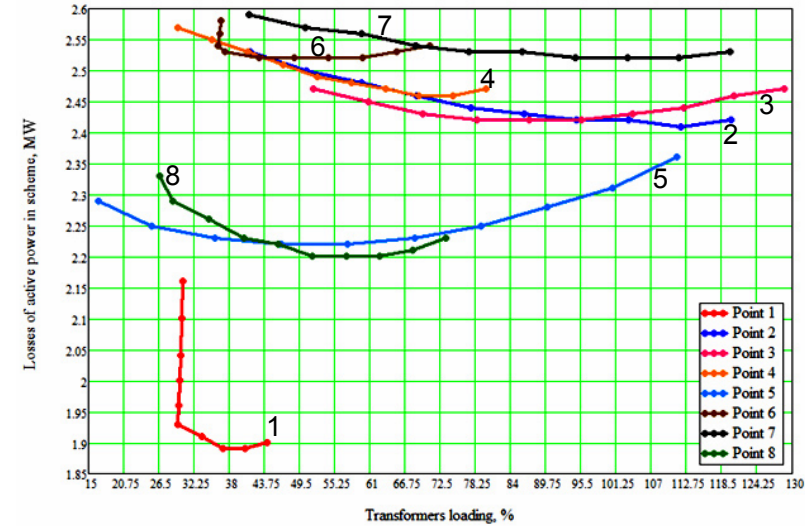

Fig. 2. Dependence of active power losses on the load of the transformer

In the presence of the SPS in the network, the active power losses is reduced with increasing generation power, except for the most remote nodes from the balancing point BP «0», in which the losses decrease of approximately up to $60 \%$ of the load of transformers takes place. At significant overloads of transformers (up to $130 \%$ ) there is an increase in reactive power losses in comparison with losses in the network without power of the SPS. The dependence of active power losses in the network on the load of transformers has a nonlinear character. For each node at one value of the load of the transformer, the active losses are different. At lower load ratios, less reactive power loss occurs. When increasing the load of transformers, the rate of increase in reactive losses is higher than the active ones.

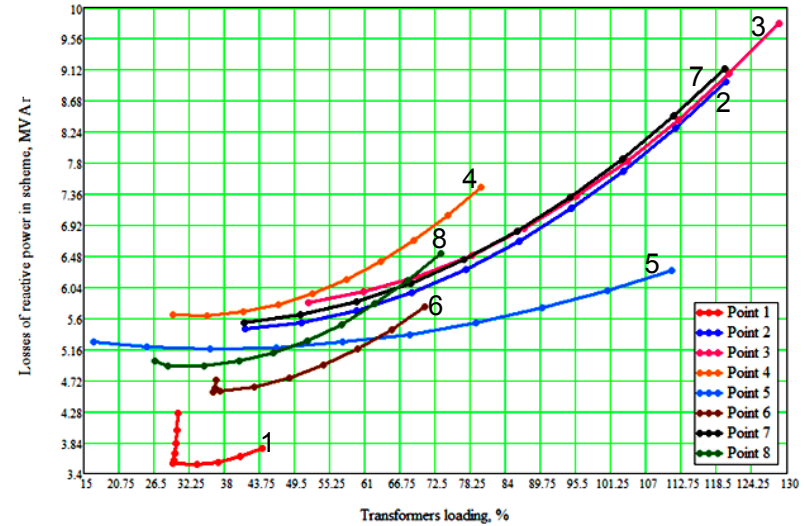

Fig. 3. Dependence of reactive power losses on the load of the transformer

Regardless of the connection place and the generation power of the SPS, the active power losses in the network are unequivocally reduced compared to the losses in the network without the introduction of the SPS. In presented in Fig. 1 network there are two nodes 1 and 5 in which there is flow distribution of power, that is, power flows along the lines feeding the nodes are directed to them from the balancing point.

In node 1 , the load is greatest compared to other nodes and is $21 \%$ of the network load (Fig. 5). In this case, the optimum power of generation of SPS, which can be introduced into a node, should be about $29 \mathrm{MW}$ at power losses at the level $\Delta S=1.89-j 3.64 \mathrm{MVA}$, the values of which are the smallest in comparison with losses when connecting SPS to other nodes. In the calculated 
mode without the introduction of generation in the network power losses are at the level $\Delta S=2.81-j 7.23$ MVA.

At node 5, the load is $10.2 \%$ of the total network load.
The optimal generation power of the SPS, which can be introduced into node 5 , should be approximately $19 \mathrm{MW}$, with power losses at the level $\Delta S=2.22-j 5.18$ MVA.

Table 3

Power losses in the network and load of transformers

\begin{tabular}{|c|c|c|c|c|c|c|c|c|c|c|c|}
\hline \multirow{2}{*}{$P_{\mathrm{SPS}}$} & \multirow{2}{*}{$\begin{array}{l}\text { Point in which } \\
\text { SPS is connected }\end{array}$} & \multicolumn{2}{|c|}{$\begin{array}{l}\text { Power losses in the } \\
\text { circuit }\end{array}$} & \multicolumn{8}{|c|}{ Load of transformers, $\%$} \\
\hline & & $\begin{array}{l}\Delta P_{\Sigma} \\
M W\end{array}$ & $\begin{array}{l}\Delta Q_{\Sigma} \\
\text { MVAr }\end{array}$ & 1 & 2 & 3 & 4 & 5 & 6 & 7 & 8 \\
\hline $0 \mathrm{MW}$ & - & 2.81 & 7.23 & 59.78 & 71.01 & 63.09 & 51.83 & 73.3 & 75 & 77.55 & 57.93 \\
\hline \multirow{8}{*}{$13 \mathrm{MW}$} & 1 & 2.16 & 4.26 & 30.35 & 70.58 & 62.82 & 51.6 & 73.1 & 74.89 & 77.51 & 57.85 \\
\hline & 2 & 2.53 & 5.45 & 59.43 & 41.42 & 62.69 & 51.77 & 73.3 & 74.84 & 77.54 & 57.91 \\
\hline & 3 & 2.47 & 5.82 & 59.54 & 70.57 & 51.75 & 51.79 & 73.3 & 74.58 & 77.54 & 57.92 \\
\hline & 4 & 2.57 & 5.65 & 59.53 & 70.93 & 63.04 & 29.65 & 73 & 74.96 & 77.48 & 57.78 \\
\hline & 5 & 2.29 & 5.27 & 59.62 & 70.96 & 63.06 & 51.58 & 16.6 & 74.99 & 77.23 & 57.23 \\
\hline & 6 & 2.58 & 4.72 & 59.69 & 70.85 & 62.71 & 51.82 & 73.3 & 36.68 & 77.54 & 57.93 \\
\hline & 7 & 2.59 & 5.54 & 59.75 & 71.01 & 63.09 & 51.79 & 73.0 & 75 & 41.31 & 57.57 \\
\hline & 8 & 2.33 & 4.99 & 59.69 & 70.99 & 63.07 & 51.69 & 72.4 & 75 & 77.03 & 26.6 \\
\hline \multirow{8}{*}{$23 \mathrm{MW}$} & 1 & 1.93 & 3.54 & 29.63 & 70.29 & 62.64 & 51.46 & 73 & 74.82 & 77.5 & 57.79 \\
\hline & 2 & 2.43 & 6.68 & 59.23 & 86.15 & 62.46 & 51.74 & 73.3 & 74.75 & 77.53 & 57.9 \\
\hline & 3 & 2.42 & 7.32 & 59.41 & 70.31 & 95.57 & 51.77 & 73.3 & 74.34 & 77.54 & 57.92 \\
\hline & 4 & 2.48 & 6.15 & 59.36 & 70.88 & 63 & 58 & 72.7 & 74.97 & 77.44 & 57.89 \\
\hline & 5 & 2.23 & 5.37 & 59.5 & 70.93 & 63.04 & 51.42 & 68.3 & 74.98 & 77 & 56.78 \\
\hline & 6 & 2.52 & 4.75 & 59.64 & 70.75 & 62.48 & 51.81 & 73.3 & 48.64 & 77.54 & 57.93 \\
\hline & 7 & 2.53 & 6.83 & 59.74 & 71 & 63.1 & 51.77 & 72.9 & 75 & 85.95 & 57.35 \\
\hline & 8 & 2.2 & 5.28 & 59.64 & 70.1 & 63.07 & 51.61 & 71.9 & 74.99 & 76.72 & 51.61 \\
\hline \multirow{8}{*}{$31 \mathrm{MW}$} & 1 & 1.9 & 3.76 & 44.19 & 70.08 & 62.52 & 51.35 & 72.9 & 74.77 & 77.47 & 57.75 \\
\hline & 2 & 2.42 & 8.95 & 59.1 & 120.06 & 62.31 & 51.72 & 73.2 & 74.71 & 77.53 & 57.9 \\
\hline & 3 & 2.48 & 9.77 & 59.32 & 70.15 & 128.7 & 51.76 & 73.3 & 74.19 & 77.54 & 57.91 \\
\hline & 4 & 2.47 & 7.45 & 59.25 & 70.84 & 62.99 & 79.96 & 72.6 & 74.97 & 77.42 & 57.62 \\
\hline & 5 & 2.36 & 6.28 & 59.44 & 70.91 & 63.03 & 51.31 & 111.1 & 74.98 & 76.89 & 56.46 \\
\hline & 6 & 2.54 & 5.76 & 59.61 & 70.69 & 82.32 & 51.81 & 73.3 & 70.79 & 77.55 & 57.93 \\
\hline & 7 & 2.53 & 9.13 & 59.74 & 71 & 68.08 & 51.76 & 72.8 & 75 & 119.81 & 27.21 \\
\hline & 8 & 2.23 & 6.52 & 59.61 & 70.96 & 63.06 & 51.56 & 71.5 & 74.99 & 76.5 & 73.38 \\
\hline
\end{tabular}

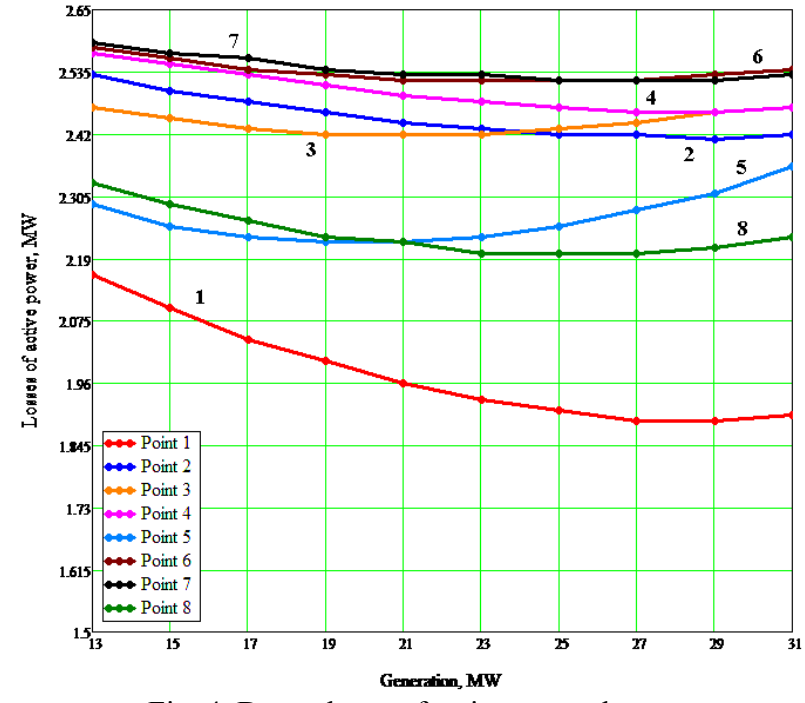

Fig. 4. Dependence of active power losses on generation power

Thus, for the investigated eight-node closed networks with voltage of $110 \mathrm{kV}$, a regularity has been found which confirms that the optimal node for connecting the DGS is the node in which the flow distribution of the power takes place. If there are several such nodes in the network, the optimal one for connecting is the node with the maximum load. The optimal power of

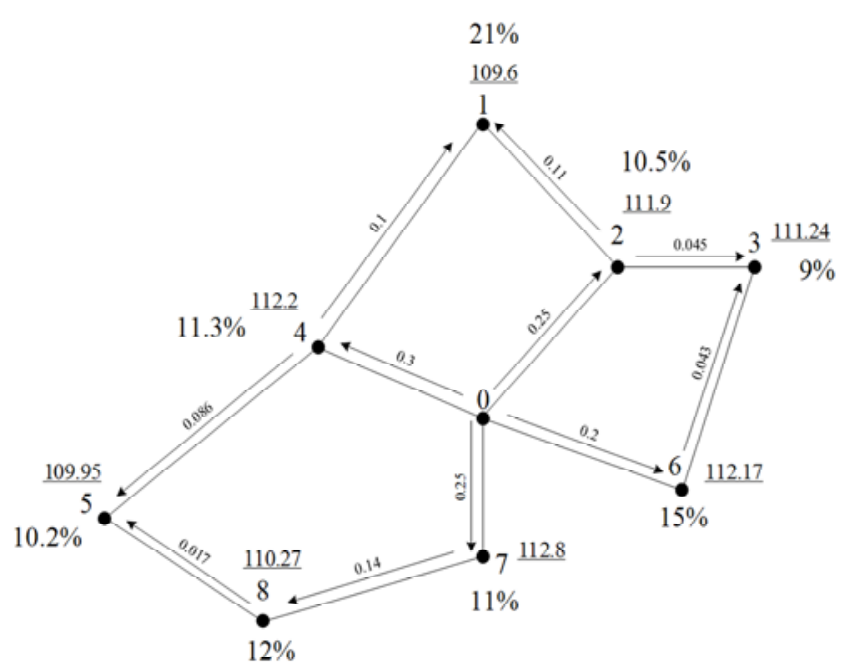

Fig. 5. The circuit of the electric network $110 \mathrm{kV}$ with coefficients of flow distribution of power

the SPS in the node should not exceed $110 \%$ of the installed transformer's power.

\section{Conclusions.}

As an optimal place to connect a source of distributed generation in a closed electric network with voltage of $110 \mathrm{kV}$, to provide the minimum value of active power losses, a node of flow distribution of power 
with the largest part of its current from the balancing point can be considered.

As the optimum value of the power of the DGS in a specific node, it is possible to accept power exceeding not more than $10 \%$ the total power of the transformers installed there.

The proposed approach will allow to perform a preliminary assessment of the location of the DGS installation and the value of its power without spending too much time for the large volumes of multivariate calculations of network operation modes.

\section{REFERENCES}

1. Pepermans G., Driesen J., Haeseldonckx D., Belmans R., D'haeseleer W. Distributed generation: definition, benefits and issues. Energy Policy, 2005, vol.33, no.6, pp. 787-798. doi: 10.1016/j.enpol.2003.10.004.

2. Kyrylenko O.V., Pavlovskyi V.V., Lukianenko L.M. Technical aspects of adoption of distributed generation sources in electric mains. Technical Electrodynamics, 2011, no.1, pp. 46-53. (Ukr).

3. Haesen E., Espinoza M., Pluymers B., Goethals I., Thong V.V., Driesen J., Belmans R., De Moor B. Optimal placement and sizing of distributed generator units using genetic optimization algorithms. Electrical Power Quality and Utilisation, 2005, vol.11, iss.1, pp. 97-104.

4. Gandomkar M., Vakilian M., Ehsan M. A combination of genetic algorithm and simulated annealing for optimal DG allocation in distribution networks. Canadian Conference on Electrical and Computer Engineering, 2005, pp. 645-648. doi: 10.1109/ccece.2005.1557013.
5. Golshan M.E.H., Ali Arefifar S. Optimal allocation of distributed generation and reactive sources considering tap positions of voltage regulators as control variables. European Transactions on Electrical Power, 2007, vol.17, no.3, pp. 219239. doi: 10.1002/etep.130.

6. Falaghi H., Haghifam M.-R. ACO Based Algorithm for Distributed Generation Sources Allocation and Sizing in Distribution Systems. 2007 IEEE Lausanne Power Tech., Jul. 2007. doi: 10.1109/pet.2007.4538377.

7. Kyrylenko O.V., Trach I.V. The technical features of the power systems functioning with integrating sources of distributed generation. Works of the Institute of Electrodynamics of the National Academy of Sciences of Ukraine, 2009, no.24, pp. 3-7. (Ukr).

8. Keane A., O'Malley M. Optimal Allocation of Embedded Generation on Distribution Networks. IEEE Transactions on Power Systems, 2005, vol.20, no.3, pp. 1640-1646. doi: 10.1109/tpwrs.2005.852115.

Received 14.02.2019

V.V. Kyryk ${ }^{1}$, Doctor of Technical Science, Professor,

O.S. Bohomolova ${ }^{1}$, Assistant Lecturer,

${ }^{1}$ National Technical University of Ukraine «Igor Sikorsky Kyiv Polytechnic Institute»,

37, Prosp. Peremohy, Kyiv, Ukraine, 03056,

phone +380 44 4068234;

e-mail: vkyryk@ukr.net, BohomolovaOS@ukr.net

How to cite this article:

Kyryk V.V., Bohomolova O.S. Justification of optimal location of connection of the distributed generation source and value of its power. Electrical engineering \& electromechanics, 2019, no.2, pp. 55-60. doi: 10.20998/2074272X.2019.2.08. 